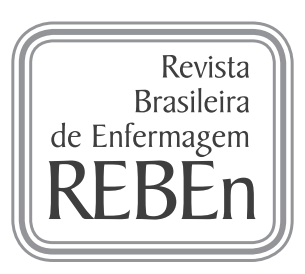

\title{
The impact of cancer on healthy siblings
}

\author{
Impacto da doença oncológica nos irmãos saudáveis \\ El impacto de la enfermedad oncológica en los hermanos sanos
}

\author{
Goreti Marques', Beatriz Araújo", Luís Sá" \\ 'Escola Superior de Saúde de Santa Maria. Porto, Portugal. \\ "Universidade Católica Portuguesa, Institute of Health Sciences. Porto, Portugal.
}

How to cite this article:

Marques G, Araújo B, Sá L. The impact of cancer on healthy siblings. Rev Bras Enferm [Internet]. 2018;71(4):1992-7.

DOI: http://dx.doi.org/10.1590/0034-7167-2016-0449

Submission: 10-01-2016 Approval: 10-01-2017

\section{ABSTRACT}

Objective: The objective is to identify the variables that influence the impact of cancer on healthy siblings. Method: This is a quantitative, descriptive and correlational study with 83 families of children with cancer. We used the "Questionnaire to Assess the Impact of the Children's Cancer on the Family", "Social Support Satisfaction Scale", "Graffar Scale" and "Apgar Scale". Results: The results show a relation between social support $\left(X^{2}=5.031, g l=1, p=0.025\right)$, expenses $(t=-2.009, g l=81, p=0.048)$, disease impact on family structure $(t=-3.210, g l=81, p=0.002)$ and the impact of the disease on healthy siblings. Conclusion: Social support plays an important role in these families, especially in the impact of the disease on healthy siblings. Nurses should identify the support systems that families have available, as well as their family functionality and the implications for healthy siblings.

Descriptors: Family Relations; Relationship Among Siblings; Oncology; Family; Siblings.

\section{RESUMO}

Objetivo: O objetivo foi identificar as variáveis que influenciam o impacto da doença oncológica nos irmãos saudáveis. Método: Estudo de natureza quantitativa, descritivo e, correlacional, com 83 famílias de crianças com doença oncológica. Recorreu-se à utilização de "Questionário de avaliação do impacto da doença oncológica da criança na família", "Escala Satisfação do Suporte Social", "Escala de Graffar" e "Escala de Apgar". Resultados: Os resultados evidenciam uma associação entre o suporte social $\left(X^{2}=5,031 ; g l=1 ; p=0,025\right)$, os gastos econômicos $(t=-2,009 ; g l=81 ; p=0,048)$, o impacto da doença na estrutura familiar ( $t=-$ $3,210 ; g l=81 ; p=0,002)$ e o impacto da doença nos irmãos saudáveis. Conclusão: O suporte social assume um papel importante nessas famílias, nomeadamente no impacto da doença nos irmãos saudáveis. Os enfermeiros devem identificar os sistemas de apoio que as famílias têm disponíveis, bem como o seu funcionamento familiar e as implicações nos irmãos saudáveis.

Descritores: Relações-Familiares; Relações entre Irmãos; Oncologia; Família; Irmãos.

\section{RESUMEN}

Objetivo: El objetivo fue identificar las variables que influencian el impacto de la enfermedad oncológica en los hermanos sanos. Método: Estudio de naturaleza cuantitativa, descriptiva y correlacional, con 83 familias de niños con enfermedad oncológica. Se recurrió a la utilización de "Cuestionario de evaluación del impacto de la enfermedad oncológica del niño en la familia", "Escala Satisfacción del Soporte Social", "Escala de Graffar" y "Escala de Apgar". Resultados: Los resultados evidencian una asociación entre el soporte social $\left(X^{2}=5,031 ; g l=1 ; p=0,025\right)$, los gastos económicos $(t=-2,009 ; g l=81$; $p=0,048)$; el impacto de la enfermedad en la estructura familiar $(t=-3,210 ; g l=81 ; p=0,002)$ y el impacto de la enfermedad en los hermanos sanos. Conclusión: El soporte social desempeña un papel importante en estas familias, especialmente en el impacto de la enfermedad en los hermanos sanos. Los enfermeros deben identificar los sistemas de apoyo que las familias tienen disponibles, así como su funcionamiento familiar y las implicaciones en los hermanos sanos.

Descriptores: Relaciones Familiares; Relaciones entre Hermanos; Oncología; Familia; Hermanos. 


\section{INTRODUCTION}

Cancer does not only affect the sick child but also the entire family. This pathology occurs in a family system, producing negative effects on the functioning of the system and on each of its elements. Thus, considering that in a system, the behavior of each of its members is inseparable from the behavior of the rest, there is a circularity in the relationship between the child and the family ${ }^{(1)}$. In the family, siblings are influenced in a mutual, complex and multifactorial way, this subsystem having a strong impact on the dynamics and the family functionality ${ }^{(2)}$.

The needs cancer treatment treatments require take the families to focus all their attention on the sick child and, in this context, the siblings suffer, not only by the constant absences of the parents, but also by their lack of attention ${ }^{(3)}$. Healthy siblings need to adapt not only to the disease, but also to a whole set of changes in their daily routines, which can lead them to experience family separations and a decrease in social contact with parents and their sick sibling ${ }^{(4)}$. The long periods of hospitalization of sick children in hospitals often away from the area of residence emphasize a decrease in communication between siblings and parents, which may hinder the process of adaptation of healthy siblings to the disease ${ }^{(5)}$. Adaptation can be facilitated when these children come from extended families and/or from families with a higher socioeconomic level( ${ }^{(2)}$.

The family focuses the care and spends a lot of time with the sick child, hoping to have support from the extended family to care for their healthy children. In this sense, grandparents are an essential resource to ensure the care of these children, since they will allow to maintain the normality of some of the family activities prior to sickness ${ }^{(6)}$.

The social support system given by other family members or friends also plays a fundamental role in the life of these families ${ }^{(7)}$, since it functions as a coping resource, acting essentially to reduce the demands of stress situations, such as caring for healthy siblings. This contributes to adjustment and adaptation to stressful situations, helping to respond to special needs, particularly those related to certain family functions, since sometimes parents cannot attend school activities for their healthy children or respond to the demands of these children against the demands of the disease itself, which requires various parental care ${ }^{(8)}$.

Families' financial and emotional resources also become child-oriented. When this happens, there is not only a decrease in the normal activities of the family, but also in the economic resources allocated to other children ${ }^{(7)}$. The needs of the sick child are prioritized while sacrificing those of other family members, namely, healthy siblings ${ }^{(9)}$.

Health professionals, particularly nurses, should be aware of the family breakdown that the disease implies, as well as the families' need for support ${ }^{(5)}$.

The literature presents studies that advance the knowledge of the impact that cancer has on the family and healthy siblings. However, we believe that it is necessary to invest in more studies that allow us to identify the impact factors of cancer on healthy siblings, in order to support nurses' interventions so that they can help families and enable them in the process adaptation to disease ${ }^{(7)}$.

\section{OBJECTIVE}

To identify the variables that influence the impact of cancer on healthy siblings.

\section{METHOD}

\section{Ethical aspects}

Underlying ethical issues are associated with any study that the investigator must adhere to. The study was approved by the Board of Directors of the Institution where it was held, as well as by the Ethics Committee of this Institution. Families of children under 18 years old and undergoing treatment were promptly contacted. After each contact, the formal aspects of the study were explained and, with families agreeing to participate, they were asked to sign the Informed Consent Form, ensuring confidentiality, privacy and anonymity. One of the tools used was the Social Support Satisfaction Scale (SSSS), which was already validated and translated into Portuguese language and culture, and only the authorization of the "author" was requested for its use.

\section{Type of study}

This is a quantitative, descriptive and correlational study. The study was conducted at a health institution in the northern region of Portugal. Eighty-one families of children with cancer with healthy siblings participated. The number of subjects was defined by the total number of families contacted in the period between August 2011 and January 2013, taking into account the defined inclusion and exclusion criteria.

\section{Design, place of study and criteira}

The data collection took place between August 2011 and January 2013 , in a health institution in the northern region of Portugal, in a room provided by the institution, where it was possible to maintain the privacy of the families. The interviews were carried out when the children were hospitalized, considering that this would be the most appropriate moment, avoiding the displacement of the families to the institution.

\section{Population or sample: inclusion and exclusion criteria}

The sample was conventional; we included families of children with cancer who had previous experience of hospitalization, who were undergoing treatments (chemotherapy/radiotherapy) and had siblings. Families of children with oncological disease were excluded: (i) in palliative care; (ii) post-transplant situation; and (iii) under surveillance (which were no longer under treatment). The number of participants was determined by the total number of families contacted in the period between August 2011 and January 2013, taking into account the exclusion criteria mentioned above. The sample consisted of 83 families of children with cancer, all of whom presented siblings and followed the inclusion criteria.

\section{Study protocol}

Following the objectives defined in the theoretical framework, it is necessary to determine the data collection instruments to be used, in order to respond to the research problem. 
In this case, the "Questionnaire to Assess the Impact of the Children's Cancer on the Family" (QAICCF), the "Social Support Satisfaction Scale (SSSS)", the "Graffar Scale" and the "Apgar Scale" were used.

The tools were applied in a form during one of the periods in which the child was hospitalized to avoid the family moving to the institution in a room provided by the service, where it was possible to maintain the privacy of families. The tools were applied to the father and the mother, with an average of 30 minutes long. During this period, children stayed in the company of volunteers in an educational entertainment room.

One of the tools used in data collection was the QAICCF, which was constructed and validated by us, with the objective of evaluating the impact of the cancer of children in families ${ }^{(10)}$. The tool is made up of two parts: in the first, it makes a sociodemographic and economic characterization of the families; in the second one, it evaluates the impact of the disease on the family by means of 47 items, with five options of answer, in a Likert scale (1- I totally disagree; - I totally agree). This tool allows to evaluate the impact of the disease in four dimensions: the Disease Impact on Healthy Siblings (DIHS) (10 items); a Family Perception of Nurses' Interventions - FPNI (10 items); Impact of the Disease on Family Structure - IDFS (15 items); and the Disease Economic Impact on Family (12 items) - DEIF. In order to compare and evaluate the internal consistency of QAICCF, we used the Chronbach alpha, with an overall alpha of 0.88 .

In this study, the dependent variable was the "impact of the disease on healthy siblings", which we evaluated through the values of one of the dimensions of QAICCF, the DIHS. This dimension (DIHS) is composed of 10 items and allowed us to evaluate the perception of families of the impact of the disease on healthy siblings, presenting a global alpha of 0.97 .

For a better statistical understanding of the results found, the study sample was divided into two groups: the group of families that agree with the "impact of the disease on healthy siblings" and the group of families that disagree. We used the association of the three indicators that we considered positive ("I neither disagree or agree", "I agree" and "I strongly agree"), considering the sum obtained in these alternative responses. The same procedure was used for the responses associated with two "Negative Indicators" ("I strongly disagree" and "I disagree") $)^{(11)}$.

Another tool used was the SSSS, which allowed us to evaluate the perception of families with their social support. This tool is composed of fifteen items presented in a Likert scale with five response positions ( 1 - I totally agree, 2 - I agree mostly, 3 - I neither agree or disagree, 4 - I strongly disagree and 5 - I totally disagree). This scale has four dimensions: "satisfaction with friends/friendship" (5 items), "intimacy" (4 items), "family satisfaction" (3 items) and "social activities" (3 items). The overall alpha value of the scale was 0.85 .

To evaluate the socioeconomic conditions of the families and to identify their social class, the Graffar scale was used. This scale classifies families in the following dimensions: profession, schooling, source of household income, convenience of the house and appearance of the house. At grade 1 corresponds to score 1; to grade 2 , score 2 , and so on. The sum of these scores will allow the family to be included in one of the following social positions: (i) Upper class (I) - from 5 to 9; (ii) Upper middle class (II) - from 10 to 13; (iii) Middle class (III) - from 14 to 17; (iv) Lower middle class (IV) - from 18 to 21; and (v) Low class (V) - from 22 to 25.

The Apgar scale was also used to evaluate family functionality and satisfaction. This scale is self-fulfilling, composed of five questions on Likert scale with three response options (1 - Almost always, 2 - Sometimes and 3 - Almost never), each having a score ranging from 0 to 10 , relative ( 7 to 10 points), with moderate dysfunction (4 to 6 points) and with strong dysfunction (0 to 3 points).

\section{Analysis of results}

In the data handling, since the variables had a normal distribution and the sample size was higher than 30 , we chose to perform parametric tests. The association between categorical variables was performed using the chi-square test. In the comparison of means between two groups, Student's t-test was used for independent samples ${ }^{(11)}$. The software Statistical Package for the Social Sciences (SPSS $®$ ) version 19 was used.

\section{RESULTS}

We present the results of the application of the tools of data collection to the 83 families of children with cancer. Regarding the socio-demographic characterization of the participants, these are predominantly nuclear and extended families (80.5\%), with the average age of parents between 30 and 40 years old. Most parents are married or have a common-law marriage (83.6\%). Schooling ranged mainly between parents who did not complete secondary education (40.6\%) and those who completed secondary education ( $27.3 \%$ ).

Regarding children, they presented ages predominantly in the school age group (36.7\%) and adolescence (33.6\%), and, in the majority, diagnoses of leukemia $(71.9 \%)$.

The study sample belonged to a middle class (42.2\%) and upper middle class (39.1\%) and most families declared themselves as "highly functional" $(75.8 \%)$ and satisfied with their social support (53\%). The mother was the main caregiver of the child in $79.7 \%$ of the cases. In most families, the sick child is the youngest child (33.6\%) and, in $25.8 \%$ of cases, the eldest son.

Figure 1 presents the sample distributed in two groups: the families that disagree and those that agree with the impact of the disease on healthy siblings.

From the reading in Figure 1, we can see that most of the families studied (55.4\%) agree with the impact that the cancer has on healthy siblings.

Table 1 describes the study of the association between "impact on healthy siblings" and socio-demographic variables of the family.

By analyzing the correlation between the perception of the "impact of cancer on healthy siblings" and some sociodemographic and socioeconomic variables, the magnitude of the associations was evaluated. Table 1 shows that there is a relationship between the variables "expenses with the sick child" ( $r=0.242, p=0.027$ ), "social support" ( $r=-0.246$, $p$ $=0.025$ ) and the "impact of the disease on healthy siblings". Regarding "social support" and the families' perception of the 
"impact of the disease on healthy siblings", the relationship between these two variables occurs in the opposite direction, the greater the "social support" of the families, the lower the "impact of disease on healthy siblings".

\section{EPIDI}

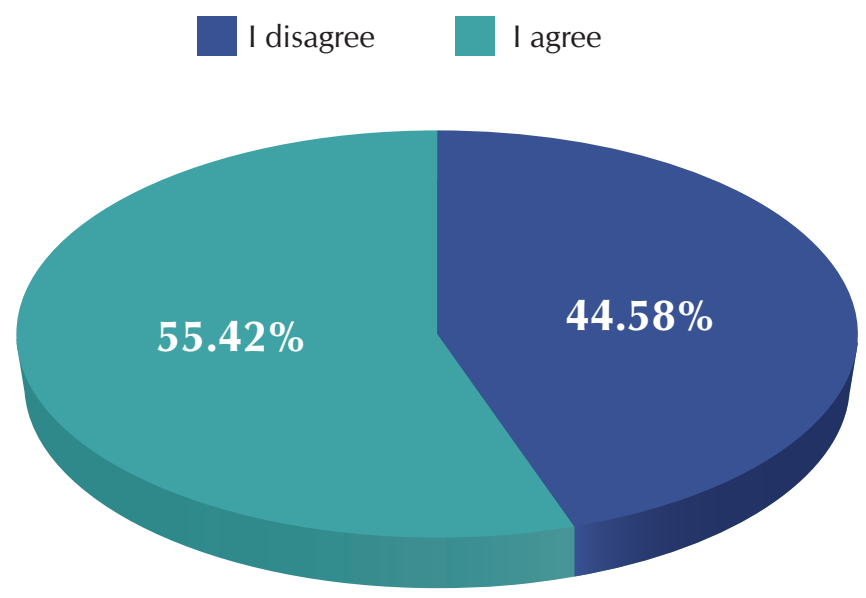

Figure 1 - Distribution of the sample in two groups

The following table shows the association between the families that agree and disagree with the "impact of the disease on healthy siblings" and the socio-demographic variables of these families.

As shown in Table 2, most "nuclear and extended families" (81.1\%) showed a lower "disease impact on healthy siblings" than singleparent families. The same was true of "highly functional families," in which $81.1 \%$ reported a lower "disease impact on healthy siblings" than "families with moderate dysfunction and strong dysfunction". Concerning "social support", the majority of satisfied families (59.5\%) reported a lower "impact of the disease on siblings". Finally, the families that showed "expenses with the sick child" (58.7\%) also presented a greater "impact of the disease on healthy siblings".

The results also showed that there is a statistically significant association between the variable "social support" $\left(X^{2}=5.031 ; g l=1\right.$; $p=0.025)$ and the "impact of the disease on healthy siblings".

Next, we compared the variation of the variables "social class," "family functionality", "social support," "expenses", and "impact on family structure" according to the families who agreed and disagreed with healthy siblings (Table 3 ).

Table 3 shows that the majority of the families that agreed with the "impact of the disease on healthy siblings" showed lower values of "social class" (3.37×3.46), belonging to a "low socioeconomic level" compared to those who disagreed with the impact.

It was also observed that

Table 1 - Matrix of correlation between the "impact of the disease on healthy siblings" and the socio-demographic variables of the family

\begin{tabular}{lcccccc}
\hline & $\begin{array}{c}\text { Type of } \\
\text { Family }\end{array}$ & $\begin{array}{c}\text { Social } \\
\text { Class }\end{array}$ & $\begin{array}{c}\text { Expenses with } \\
\text { the sick child }\end{array}$ & $\begin{array}{c}\text { Number } \\
\text { of siblings }\end{array}$ & $\begin{array}{c}\text { Place the } \\
\text { child occupies } \\
\text { in the phratry }\end{array}$ & $\begin{array}{c}\text { Social } \\
\text { support }\end{array}$ \\
\hline $\begin{array}{l}\text { Impact of the } \\
\text { disease on healthy } \\
\text { siblings }\end{array}$ & 0.085 & -0.017 & $0.242^{*}$ & 0.028 & 0.028 & $-0.246^{*}$ \\
\hline
\end{tabular}

Note: ${ }^{*} p<0.01 ;{ }^{*} p<0.05$.

Table 2 - Association between the impact of the disease on healthy siblings and family socio-demographic variables

\begin{tabular}{|c|c|c|c|c|c|c|}
\hline \multicolumn{7}{|c|}{ Impact of the disease on healthy siblings } \\
\hline & & \multicolumn{2}{|c|}{ I disagree } & \multicolumn{2}{|c|}{ I agree } & \multirow[b]{2}{*}{$p$} \\
\hline & & $\mathbf{n}$ & $\%$ & $\mathbf{n}$ & $\%$ & \\
\hline \multirow[t]{2}{*}{ Type of Family } & Nuclear and extended family & 30 & 81.1 & 34 & 73.9 & 0.440 \\
\hline & Single-parent family & 7 & 18.9 & 12 & 26.1 & \\
\hline \multirow[t]{4}{*}{ Schooling level } & Higher Education & 7 & 18.9 & 5 & 10.9 & 0.386 \\
\hline & Complete secondary education & 11 & 29.7 & 9 & 19.6 & \\
\hline & Incomplete secondary education & 14 & 37.8 & 22 & 47.8 & \\
\hline & Complete primary education & 5 & 13.5 & 10 & 21.7 & \\
\hline \multirow[t]{3}{*}{ Expenses with the sick child } & Few and some times & 11 & 26.7 & 7 & 15.2 & 0.086 \\
\hline & Many times & 13 & 35.1 & 12 & 26.1 & \\
\hline & Always & 13 & 35.1 & 27 & 58.7 & \\
\hline \multirow[t]{3}{*}{ Family Functionality } & Family with strong dysfunction & 2 & 5.4 & 4 & 8.7 & 0.487 \\
\hline & Family with moderate dysfunction & 5 & 13.5 & 10 & 21.0 & \\
\hline & Highly functional family & 30 & 81.1 & 32 & 69.9 & \\
\hline \multirow[t]{2}{*}{ Social Support } & Insatisfied social support & 15 & 40.5 & 30 & 65.2 & 0.025 \\
\hline & Satisfied social support & 22 & 59.5 & 16 & 34.8 & \\
\hline
\end{tabular}
the majority of the families that showed "disease impact on healthy siblings" had lower values of "family functionality" (Mean $=2.61$ ), that is, families with moderate or strong dysfunction, comparatively with those who disagreed. In the context of social support, the majority of families who agreed with the "impact of the disease on healthy siblings" reported, on average, less satisfaction with their "social support" (Mean $=49.28$ ) than those who disagreed. Regarding the "expenses with the sick child", the majority of the families that demonstrated "disease impact on healthy siblings" had, on average, more "economic expenses with the disease" (Mean $=4.41$ ) compared to the families that disagreed. Regarding the relationship between the "impact of the disease on healthy siblings" and the "impact of the disease on family structure", the majority of the families that showed an "impact of the disease on siblings" reported, on average, a greater disease in the family structure" (56.50 x 50.19). 
Table 3 - Comparison between Graffar and Apgar scales, social support, expenses, impact on family structure according to agreement/disagreement of the impact on healthy siblings

\begin{tabular}{|c|c|c|c|c|c|}
\hline & Impact of the disease on healthy siblings & $\mathbf{n}$ & Mean & SD & $p$ \\
\hline Social class & $\begin{array}{l}\text { I disagree } \\
\text { I agree }\end{array}$ & $\begin{array}{l}37 \\
46\end{array}$ & $\begin{array}{l}3.46 \\
3.37\end{array}$ & $\begin{array}{l}0.69 \\
0.74\end{array}$ & 0.573 \\
\hline Family functionality & $\begin{array}{l}\text { I disagree } \\
\text { I agree }\end{array}$ & $\begin{array}{l}37 \\
46\end{array}$ & $\begin{array}{l}2.76 \\
2.61\end{array}$ & $\begin{array}{l}0.55 \\
0.65\end{array}$ & 0.272 \\
\hline Social support & $\begin{array}{l}\text { I disagree } \\
\text { I agree }\end{array}$ & $\begin{array}{l}37 \\
46\end{array}$ & $\begin{array}{l}55.57 \\
49.28\end{array}$ & $\begin{array}{l}10.65 \\
10.67\end{array}$ & 0.009 \\
\hline Expenses with the sick child & $\begin{array}{l}\text { I disagree } \\
\text { I agree }\end{array}$ & $\begin{array}{l}37 \\
46\end{array}$ & $\begin{array}{l}4.05 \\
4.41\end{array}$ & $\begin{array}{l}0.81 \\
0.80\end{array}$ & 0.048 \\
\hline Impact of the disease on Family structure & $\begin{array}{l}\text { I disagree } \\
\text { I agree }\end{array}$ & $\begin{array}{l}37 \\
46\end{array}$ & $\begin{array}{l}50.19 \\
56.50\end{array}$ & $\begin{array}{c}10.48 \\
7.40\end{array}$ & 0.003 \\
\hline
\end{tabular}

Note: SD-Standard Deviation

By reading the results in Table 3, there was a statistically significant difference in mean values between the variables "social support" $(t=2,668, g l=81, p=0.009)$, "expenses with the sick child" ( $\mathrm{t}=-2.009, \mathrm{gl}=81, \mathrm{p}=0.048)$, and "disease impact on family structure" $(t=-3.210, \mathrm{gl}=81, \mathrm{p}=0.002)$ between the groups of "impact of the disease on healthy siblings".

\section{DISCUSSION}

Regarding the impact of cancer on healthy siblings, this does not seem to be affected by socio-demographic characteristics, in general. This result is also evidenced by some studies ${ }^{(1,5,8)}$ that highlight the negative effects that this disease causes in healthy siblings compared to healthy children, and the negative effects that cancer causes in family functionality, regardless of their socio-demographic characteristics, because it happens in a family context in which the child and siblings are inserted ${ }^{(1)}$.

The families of this study were predominantly nuclear and extended and belonged to a middle class, which, according to other studies ${ }^{(2,6)}$, may also contribute to a more flexible adaptation of healthy siblings to the disease. Support from the extended family will be an essential resource to ensure care for these children, while allowing family and children to maintain normal family activities prior to sickness ${ }^{(6)}$.

We found that the impact of the disease on healthy siblings is significantly associated with "expenses with the sick child", "social support" and "impact on family structure". The long periods of hospitalization of sick children in remote hospital centers, as well as all the inherent specificities of the disease itself, generate increased expenses ${ }^{(3,5)}$, which, within the family system, are oriented towards the sick child, not only occurring reduction in the normal activities of the family, but also in the economic resources destined to other children ${ }^{(6)}$. The needs of the sick child are prioritized to the detriment of other family members, namely, the healthy siblings ${ }^{(9)}$.

In relation to "social support", it is evident that families with lower disease impact on healthy siblings present a higher satisfaction with this support. Social support plays a fundamental role in the life of these families because, during the long periods of hospitalization of the child, the siblings are cared for by other relatives or friends ${ }^{(7)}$, which constitute an essential resource to ensure continuity of care for other children ${ }^{(8)}$. It functions in the life of these families as a coping resource, helping them to care for their healthy children ${ }^{(7)}$.

We also found that the greater the "social support" of the families, the lower the impact of the disease on healthy siblings. This reinforces once again its importance, insofar as it contributes to the adaptation to the disease, helping families to respond to certain family functions, such as attending school activities or attending to other requests of these healthy children ${ }^{(8)}$.

One of the results showed that the greater the impact of cancer on healthy siblings, the greater the "impact of the disease on family structure". It is important to point out that this disease occurs within a context and family system, producing negative effects in each of its elements and, in particular, healthy siblings, therefore, taking into account the General Theory of Systems, nothing happens in isolation, and something that affects one of the components affects all others, that is, any change in one of the elements of the family has an impact on all other members of that system ${ }^{(1)}$. Within the family system, siblings influence each other, having a strong impact on their dynamics and functionality ${ }^{(2)}$. Family separations and changes in the routines experienced by the siblings can lead to a decrease in social contact and communication itself with parents and siblings ${ }^{(4)}$.

\section{Study limitations}

One of the main limitations of this study is that the results of this research highlight the perceptions of the families, and it is necessary to develop more studies, especially with the siblings. However, the results suggest some interventions for nurses, such as models of family care partnerships in which siblings are involved.

\section{Contributions to the Nursing sector}

With this study, we hope to have contributed to the identification of some of the factors that interfere in the impact of the disease on healthy siblings, thus allowing nurses to carry out 
interventions involving healthy siblings in the care for the sick child and to identify the needs of families.

\section{CONCLUSION}

In view of the results, it was possible to identify some of the variables that may influence the impact of cancer on healthy siblings.

The results of our study indicate that healthy siblings whose families have the greatest impact of the disease on the family structure and increased expenses with the child's sickness show a greater impact of the disease on healthy siblings. On the other hand, the families that declare themselves more satisfied with the social support provided to them, report less impact with this pathology.
Regarding the socio-demographic variables of the families, the results do not show statistical values that justify their influence on the impact of the disease on healthy siblings.

We found that social support assumes an important role in these families, namely by their relation in reducing the impact of the disease on healthy siblings. We believe that nurses need to be aware of the needs of families to plan coherent and appropriate interventions. The results of the study allow us to suggest some actions, such as the identification by nurses of the support systems that families have available, as well as the family functionality and the implications that the disease causes in healthy siblings.

In conclusion, we believe that it is necessary to make health professionals, such as nurses, aware of the importance of the family as a focus of care.

\section{REFERENCES}

1. Duarte MLC, Zanini LN, Nedel MNB. O cotidiano dos pais de crianças com câncer e hospitalizadas. Rev Gaúcha Enferm[Internet]. 2012[cited 2017 Sep 21];33(3):111-8. Available from: http://www.scielo.br/pdf/rgenf/v33n3/15.pdf

2. Price J. The significant effects of childhood cancer on siblings. Cancer Nurs Pract[Internet]. 2012[cited 2017 Sep 21];11(4):26-31. Available from: http://dx.doi.org/10.1590/S1983-14472012000300015

3. Cheron M, Pettengill M. Experience of healthy in relation to the disease hospitalization of his brother with cancer. Acta Paul Enferm[Internet]. 2011[cited 2017 Sep 21];24(5):605-10. Available from: http://www.scielo.br/pdf/ape/v24n5/02v24n5.pdf

4. Anjos C, Santo F, Carvalho E. Childhood cancer in the family environment: an integrative review. Rev Min Enferm[Internet]. 2015[cited 2017 Sep 21];19(1):234-40. Available from: http://dx.doi.org/10.5935/1415-2762.20150018

5. Malone A, Price J. The significant effects of childhood cancer on siblings. Cancer Nurs Pract[Internet]. 2012 [cited 2017 Sep 21];11(4):11-9. Available from: http://dx.doi.org/10.7748/cnp2012.05.11.4.26.c9095

6. Bernardes I, Pegoraro R. Brothers of healthy child with cancer: integrative review of literature. Esp Saúde[Internet]. 2015 [cited 2017 Sep 21];6(4):98-108. Available from: http://pesquisa.bvsalud.org/portal/resource/pt/biblio-834524 Portuguese

7. Souza R, Costa G, Yamashita C, Amendola F, Gaspar J, Alvarenga M, et al. Family functioning of elderly with depressive symptoms. Rev Esc Enferm USP[Internet]. 2014[cited 2017 Sep 21];48(3):469 76. Available from: http://www.scielo.br/pdf/reeusp/v48n3/00806234-reeusp-48-03-469.pdf

8. Kohlsdorf M, Costa Jr A. Psychosocial impact of pediatric cancer on parents: a literature review. Paidéia[Internet]. 2012 [cited 2017 Sep 21];22(51):119-29. Available from: http://www.scielo.br/pdf/paideia/v22n51/en_14.pdf

9. Araujo BY, Reichert SPA, Oliveira GRB, Collet N. Apoio social de famílias de crianças com doença crónica: revisão integrativa. Ciênc Cuid Saúde[Internet]. 2011[cited 2017 Sep 21];10(4):853-60. Available from: http://periodicos.uem.br/ojs/index.php/ CiencCuidSaude/article/view/18332

10. Marques G, Araújo B, Sá L. A doença oncológica da criança na família: construção e validação de um questionário. Rev Esc Enferm USP. [ahead of print].

11. Marôco J. Análise Estatística com SPSS o Statistics. Pero Pinheiro; 5ª ed. 2011 